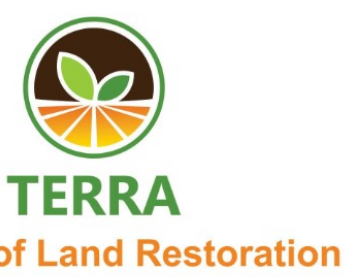

\title{
Application of Humic Acid and Arbuscular Mycorrhizal Fungi to Increase Growth and Yields of Soybean in Ultisol
}

\author{
Rahayu Arraudah $^{1}$, Yudhy Harini Bertham ${ }^{2 *}$, Hesti Pujiwati ${ }^{1}$, Bambang Gonggo Murcitro ${ }^{2}$, \\ Entang Inoriah Sukarjo ${ }^{1}$ \\ ${ }^{1}$ Agroecotechnology Department, University of Bengkulu \\ ${ }_{2}^{2}$ Soil Science Department, University of Bengkulu (Corresponding author) \\ e-mail: yudhyhb@unib.ac.id
}

\begin{abstract}
Soybean is one of the most popular food crops for the community, but the needs for soybeans have not been fulfilled by soybean production. To meet the needs of soybeans, it is necessary to intensify agricultural land in Ultisol. This study aims to obtain the optimum concentration of humic acid and dosage of the Arbuscular Mycorrhizal Fungi $(A M F)$ to increase soybean plants' production in Ultisols. This research was conducted from January to April 2020 in Beringin Raya Village, Muara Bangkahulu District, Bengkulu City, at an altitude of $10 \mathrm{~m}$ above sea level. The research design used a Randomized Complete Block Design (RCBD) two factors with three replications, arranged factorially in experimental units. The first factor is the concentration of humic acid, consisting of 4 levels: 0, 15, 30, and $45 \mathrm{~mL} \mathrm{~L}^{-1}$. The second factor is the dose of AMF, consisted of 3 levels, namely: 0, 2.5, and $5 \mathrm{~g}$ plant ${ }^{-1 .}$ The results showed that the maximum soybean growth and yield in Ultisols were obtained from the humic acid concentration at $45 \mathrm{~mL} \mathrm{~L}^{-1}$ at the dose of AMF at $2.5 \mathrm{~g}$ plant $^{-1}$. The resulting production potential is 1.99 tons $\mathrm{ha}^{-1}$. The administration of humic acid or AMF independently at this research stage had not yet given a maximum response to the growth and yield of soybean in Ultisol.
\end{abstract}

Keywords: soybean, Ultisol, humic acid, Arbuscular Mycorrhizal Fungi

\section{INTRODUCTION}

Soybean (Glycine max (L.) Merrill) is one of the most popular food crops globally, especially in Indonesia. Soybeans are used as staple food preparations, such as tempeh, tofu, taco, soy milk, and other food industry products. The advantage of soy is that it has a protein content of $40 \%$. For every $100 \mathrm{~g}$ of soybean seeds, there are also $21 \mathrm{~g}$ of carbohydrates, $7 \mathrm{~g}$ of fiber, and $2.76 \mathrm{~g}$ of magnesium (Winarsi, 2010).

The need for soybeans in Indonesia in 2015 reached more than 3 million tons, while soybean production in 2013-2015 was an average of 899,390 tons (Badan Pusat Statistik, 2016). Efforts to cover the soybean shortage have forced the country to import soybean from abroad. Based on data from the Central Statistics Agency (Badan Pusat Statistik, 2019), soybean imports in 2016-2018 have increased, the peak is as much as 2.58 million tons. Low domestic soybean production, one of the impacts of the lack of fertile land for soybean cultivation, is due to converting agricultural land to residential areas. One of the potential land for agriculture in Indonesia is marginal land from the Ultisols.

Ultisol soil is land with advanced leaching rates or acid forest soil with low fertility (Hakim, 2019). The land area of Ultisol is 107.36 million hectares or $74.31 \%$ of the 188.03 million hectares of agricultural land in Indonesia. Available in parts of the island of Kalimantan, Sumatra, and Papua (Pertanian, 2018) The main constraints in utilizing Ultisol soil are the high acidity and aluminum saturation (Al), low nutrient content, and sensitivity to erosion. The high solubility of $\mathrm{Al}$ and iron $(\mathrm{Fe})$ absorbs phosphorus $(\mathrm{P})$, so the availability of $\mathrm{P}$ for plants is low (Barchia, 2008). One of the improvements in Ultisol soil properties is the provision of organic materials such as mycorrhizae.

Mycorrhiza is a term that describes the symbiotic relationship between plant roots and fungi. The structure of AMF hyphae in plant roots can increase nutrient 
and water exchange between plants and hosts. It has excellent potential to increase nutrient uptake and translocation, especially P elements to plants (Utama \& Yahya, 2003). Research by Wardhani et al. (2019) found that mycorrhizal application as much as $7.5 \mathrm{~g}$ plant $^{-1}$ had no significant effect on $\mathrm{P}$ uptake and growth response of soybean plants but was able to increase available $\mathrm{P}$ in Ultisol soil. Another moment, the application of AMF was able to increase soybean production on Ultisols from AMF inoculant treatment of $\pm 1,000$ spores with a combination of cow manure as much as 20 tons ha ${ }^{-1}$. However, cow manure has not significantly affected the response to growth and yield of soybean with AMF (Malik et al., 2017). So, a new solution for AMF companion in Ultisols is needed, one of which is by giving humic acid.

Humic acid is a macromolecular organic acid with acidic properties determined by the $-\mathrm{COOH}$ and $-\mathrm{OH}$ phenolic groups; these groups are the most reactive in binding metal cations (Stevenson, 1994). Carboxylate groups $(-\mathrm{COOH})$ will dissociate at soil $\mathrm{pH} . \mathrm{H}+$ ions are firmly bound to organic soil colloids in acidic conditions, so they are not easily replaced by other cations (Handayanto et al., 2017). Humic acid binds to the $\mathrm{Fe}^{3+}$ and $\mathrm{Al}^{3+}$ cations (abundant in Ultisol soil). A trivalent cation is deposited, and the sediment dissolves again, along with an increase in $\mathrm{pH}$ above 7 (Santosa, 2014). Research 1,200 ppm humic acid treatment was the best treatment in increasing $\mathrm{P}$ uptake and growth of soybean plants (Wahyuningsih et al., 2016). Besides, soils with residual effects of humic acid at a rate of $600 \mathrm{ppm}$ can also suppress soil Fe solubility to near non-toxic levels, with the lowest soil Fe solubility range between 36.08-68.56 ppm (Ruhaimah et al., 2009).

This study aims to obtain the optimum interaction of humic acid concentration at several AMF doses on the growth and yield of soybean in Ultisols. and determine the optimum concentration of humic acid and the optimum amount of AMF on the growth and yield of soybean in Ultisols

\section{MATERIAL AND METHOD}

The research was carried out from January to April 2020 in community agricultural gardens, Beringin Raya Village, Muara Bangkahulu District, Bengkulu, at $10 \mathrm{~m}$ above sea level. The research design used a Randomized Complete Block Design (RCBD) two factors with three replications, arranged factorially in experimental units. The first factor was the concentration of humic acid, consisting of 4 levels: $0,15,30$, and $45 \mathrm{~mL} \mathrm{~L}^{-1}$. The second factor was the dose of AMF, which consisted of 3 levels, namely: 0 , 2.5 , and $5 \mathrm{~g} \mathrm{plant}^{-1}$. The FMA inoculant in this study was obtained from the Laboratory of Soil Biology, Faculty of Agriculture, University of Bengkulu. The humic acid used was obtained from commercial liquid humic acid.

Soil analysis was carried out before land processing to analyze $\mathrm{C}$-organic, $\mathrm{pH}$, total $\mathrm{N}$ content, total $\mathrm{P}$, total K, soil CEC and Al-dd (Al Ghifari et al., 2014). Soil management is in the form of cleaning the soil from weeds manually, processed with hoes. Map the experiment measuring $1.5 \mathrm{~m} \times 2 \mathrm{~m}$ with the distance between the plots is $50 \mathrm{~cm}$, and the distance between replicates is $1 \mathrm{~m}$.

Basic fertilization is carried out a week before planting: organic fertilizer (cow manure) 10 tons ha ${ }^{-1}$, followed by urea $25 \mathrm{~kg} \mathrm{ha}^{-1}, \mathrm{KCl} 50 \mathrm{~kg} \mathrm{ha}^{-1}$, and SP36 $50 \mathrm{~kg} \mathrm{ha}^{-1}$ at planting. The planting hole is made by cutting $3 \mathrm{~cm}-5 \mathrm{~cm}$ deep. Soybean seeds are planted two seeds in each planting hole, with a spacing of 20 $\mathrm{cm} \times 30 \mathrm{~cm}$. Humic acid and AMF applications were carried out during planting.

Harvesting is done two times. Vegetative harvesting was carried out at 30 days after planting, with 3 sample plants per plot to take intact stems and soil around the rhizosphere. Generative harvest at 95 days after planting as many as 5 sample plants, when $95 \%$ of the soybean pods are brownish yellow, the leaves begin to fall, and the stems begin to dry out according to the variety description (Balai Penelitian Tanah, 2009). Generative harvesting is carried out in the morning to evening.

The observed growth and yield variables included: soil $\mathrm{pH}$, percentage of root colonization, number and weight of nodules, plant height, number of leaves, number of productive nodes, number of pods, number of pithy pods, number and weight of seeds per plant, the weight of 100 seeds, dry stover weight, and P-tissue content. The data obtained were analyzed by analysis of variance (ANOVA) with a 5\% significance level of the Orthogonal Polynomial test (OP) to compare the effect between treatments (Gomez \& Gomez, 1983).

\section{RESULT AND DISCUSSION}

The results of the analysis of variance showed that the interaction between humic acid and AMF gave different responses significantly to soil $\mathrm{pH}$, nodule weight, plant height, number of leaves, tissue $\mathrm{P}$ content, and seed weight per plant. The application of humic acid independently was significantly different from soil $\mathrm{pH}$, the number of nodules, and dry stover weight. Meanwhile, AMF inoculation was significantly different from soil $\mathrm{pH}$, root colonization percentage, number of seeds per plant, seed weight per plant, and dry stover weight. The variable number of productive books, number of pods, number of pithy pods, and weight of 100 seeds did not show a significantly different response from all treatments (Table 1).

The analysis results of the interaction between humic acid and AMF had a significant effect on soil 
Table 1. Summary of Variance Analysis

\begin{tabular}{|c|c|c|c|c|c|}
\hline \multirow{2}{*}{ No } & \multirow{2}{*}{ Variables } & \multicolumn{3}{|c|}{ Treatments (F-count) } & \multirow{2}{*}{$\begin{array}{c}\text { Coefficient } \\
\text { of variance } \\
(\%)\end{array}$} \\
\hline & & Interaction & Humic Acid & $\mathrm{AMF}$ & \\
\hline 1 & Soil pH & $10,98^{*}$ & $12,35^{*}$ & $26,71^{*}$ & 4,17 \\
\hline 2 & Root colonization & $1,82^{\text {ns }}$ & $1,20^{\text {ns }}$ & $19,45^{*}$ & 37,37 \\
\hline 3 & Number of root nodules & $1,93^{\text {ns }}$ & $6,28 *$ & $3,40^{\mathrm{ns}}$ & 18,46 \\
\hline 4 & Weight of root nodules & $2,76^{*}$ & $0,70^{\mathrm{ns}}$ & $1,84^{\mathrm{ns}}$ & 4,07 \\
\hline 5 & Plant height $(\mathrm{cm})$ & $3,04 *$ & $2,33^{\mathrm{ns}}$ & $2,50^{\mathrm{ns}}$ & 4,46 \\
\hline 6 & Number of leaves & $3,78^{*}$ & $1,40^{\mathrm{ns}}$ & $0,98^{\mathrm{ns}}$ & 13,78 \\
\hline 7 & Number of productive books & $1,08^{\mathrm{ns}}$ & $1,76^{\mathrm{ns}}$ & $0,58^{\mathrm{ns}}$ & 8,65 \\
\hline 8 & Number of pods & $0,91^{\mathrm{ns}}$ & $0,83^{\mathrm{ns}}$ & $0,59^{\mathrm{ns}}$ & 28,89 \\
\hline 9 & Number of pithy pods & $1,37^{\mathrm{ns}}$ & $0,60^{\text {ns }}$ & $0,99^{\text {ns }}$ & 27,48 \\
\hline 10 & Number of seeds/plant ${ }^{-1}$ & $2,45^{\text {ns }}$ & $0,25^{\text {ns }}$ & $4,08^{*}$ & 26,04 \\
\hline 11 & Weight of seeds/plant ${ }^{-1}$ & $2,77^{*}$ & $0,43^{\text {ns }}$ & $4,03 *$ & 32,24 \\
\hline 12 & Weight of 100 seeds & $1,16^{\mathrm{ns}}$ & $0,01^{\text {ns }}$ & $0,75^{\mathrm{ns}}$ & 7,13 \\
\hline 13 & Dry stover weight & $0,79^{\text {ns }}$ & $7,96^{*}$ & $6,03 *$ & 24,61 \\
\hline 14 & Number of P-tissues content & $4,86^{*}$ & $2,93^{\mathrm{ns}}$ & $0,75^{\mathrm{ns}}$ & 20,77 \\
\hline
\end{tabular}

Note: ${ }^{\text {ns }}=$ does not differ significantly, ${ }^{*}=$ different significantly at the F-table level at $5 \%$.

$\mathrm{pH}$, nodule weight, plant height, number of leaves, Ptissue content, and seed weight per plant. The results of the further orthogonal polynomial test for those variables showed in Figures 1 to 6.

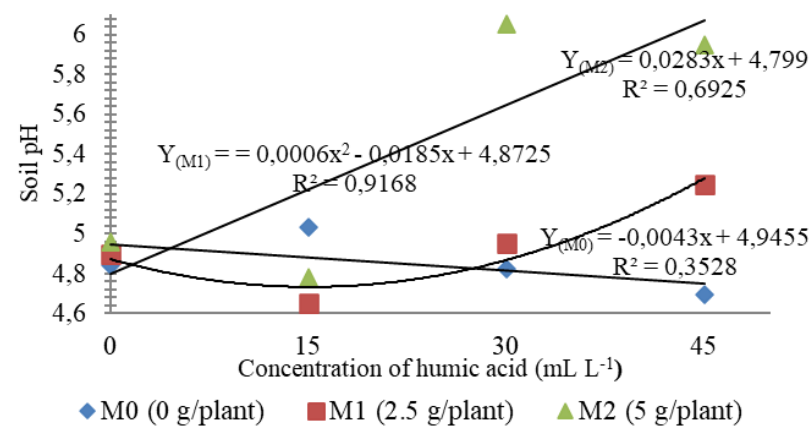

Figure 1. Relationship of humic acid concentration and soil $\mathrm{pH}$ at several AMF doses

The relationship between humic acid concentration and soil $\mathrm{pH}$ at the AMF dose of $5 \mathrm{~g} \mathrm{plant}^{-1}\left(\mathrm{M}_{2}\right)$ is a linear pattern with the equation $\mathrm{Y}\left(\mathrm{M}_{2}\right)=0.0283 \mathrm{x}+$ 4.799. Soil $\mathrm{pH}$ can increase by 0.0283 , along with the increase in the concentration of humic acid at the AMF dose of $5 \mathrm{~g} \mathrm{plant}^{-1}$. The maximum potential $\mathrm{pH}$ that can be achieved is 6.07 . The degree of determination $\left(\mathrm{R}^{2}\right)$ is 0.6925 , meaning that $69.25 \%$ of the soil $\mathrm{pH}$ variability can be determined by the $\mathrm{Y}$ equation
$\left(\mathrm{M}_{2}\right)$. On the other hand, the relationship of humic acid concentration at the AMF dose of $2.5 \mathrm{~g}$ plant $\left(\mathrm{M}_{1}\right)$ to soil $\mathrm{pH}$ formed a parabolic quadratic pattern. The equation formed is $\mathrm{Y}\left(\mathrm{M}_{1}\right)=0.0006 \mathrm{x}^{2}-0.0185 \mathrm{x}+$ 4.8725 with $\mathrm{R}^{2}=0.9168$. This indicates that giving the optimum concentration of humic acid $15.41 \mathrm{~mL} \mathrm{~L}$ ${ }^{-1}$ at an AMF dose of $2.5 \mathrm{~g} /$ plant will result in minimal soil $\mathrm{pH}$. It is different when giving humic acid without AMF inoculation; it forms a negative linear pattern, with the equation $\mathrm{Y}\left(\mathrm{M}_{0}\right)=0.0043 \mathrm{x}$ 4.9455. Giving humic acid independently when the concentration is increased will decrease the soil $\mathrm{pH}$ by 0.0043 . However, the value of $\mathrm{R}^{2} \mathrm{Y}\left(\mathrm{M}_{0}\right)$ is only 0.3528 , meaning that the variability of soil $\mathrm{pH}$ can only be explained by $35.28 \%$ of the $\mathrm{Y}\left(\mathrm{M}_{0}\right)$ equation, or in other words, $64.72 \%$ is influenced by factors outside the treatment (Figure 1).

In general, administration of humic acid with a concentration of $45 \mathrm{~mL} \mathrm{~L}^{-1}$ in AMF inoculation $5 \mathrm{~g}$ plant $^{-1}$ has the potential to reach a maximum soil $\mathrm{pH}$ of 6.07 ; or in other words, it has succeeded in increasing the soil $\mathrm{pH}$ by $31.1 \%$ from the initial soil $\mathrm{pH}$, it was 4.36. Compared with the research of Khairuna et al. (2015) AMF inoculation and compost gave the highest soil $\mathrm{pH}$ value of 5.76. The comparison of these results indicated that the interaction between AMF and humic acid was more effective in improving Ultisols' chemical properties. 


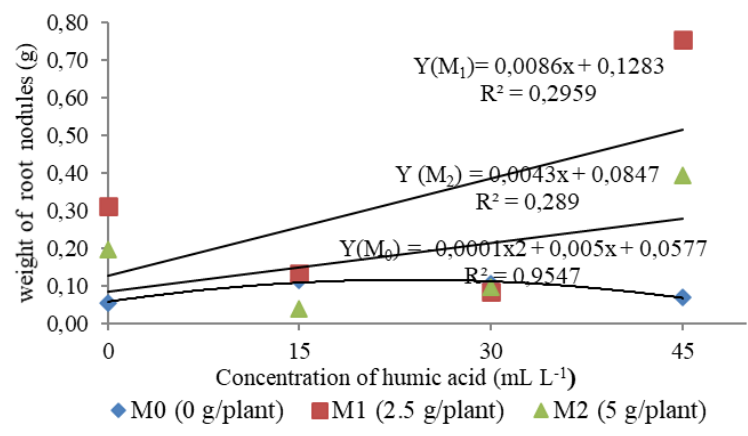

Figure_2. Relationship of humic acid and weight of root nodules at several AMF doses

Humic acid and AMF inoculation have the same function in improving soil properties: decomposing ions bound by $\mathrm{Fe}$ or $\mathrm{Al}$ in Ultisol soil. The increase in soil $\mathrm{pH}$ occurs due to the increase in $\mathrm{OH}$ - ions in the soil solution. Humic acid is known to contain $\mathrm{COOH}$ (carboxyl) and $-\mathrm{OH}$ (phenolic), which are a source of negative charges (Stevenson, 1994). Besides, biological fertilizers can increase soil $\mathrm{pH}$ because it releases organic acids in the soil (Bertham, 2002). AMF in this study as a biological fertilizer. The role of AMF, in particular, lies in phosphorus uptake. Changes in $\mathrm{pH}$ in the rhizosphere impacted an important role in phosphorus availability (Purwati et al., 2019). Thus, the interaction of humic acid and AMF to improve soil properties is realized through the working mechanisms of humic acid and AMF, which support one another. Suppose AMF, through its enzymatic process, can decompose $\mathrm{Al}$ and $\mathrm{Fe}$ (Khairuna et al., 2015), humic acid will bind to the $\mathrm{Al}$ and $\mathrm{Fe}$ cations by donating negative ion groups, thereby increasing soil $\mathrm{pH}$.

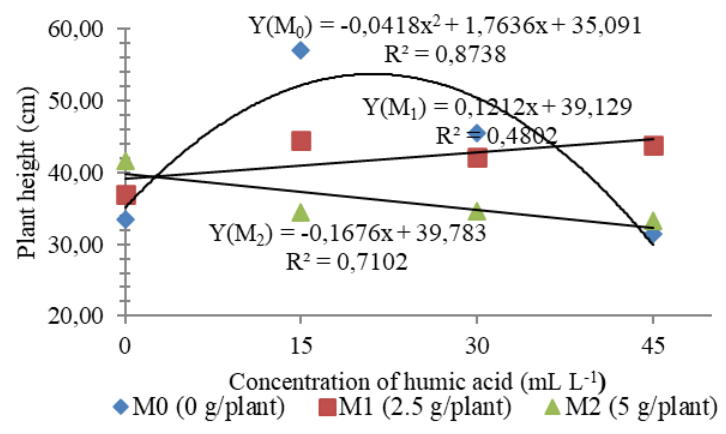

Figure 3. Relationship of humic acid concentration and plant height at several AMF doses

Changes in soil $\mathrm{pH}$ value indirectly affect plant growth components, one of which is the weight of root nodules the relationship between nodule weight and humic acid concentration at several AMF doses presented in Figure 2. The correlation pattern of humic acid concentration at the AMF dose of $5 \mathrm{~g}$ plant $^{-1}\left(\mathrm{M}_{2}\right)$ to the nodules' weight formed a linear pattern, with the equation $\mathrm{Y}\left(\mathrm{M}_{2}\right)=0.0043 \mathrm{x}+0.0847$. That indicates that the increase in humic acid concentration at the AMF dose of $5 \mathrm{~g}_{\text {plant }}{ }^{-1}$ will be accompanied by an increase in root nodule weight of $0.0043 \mathrm{~g}$. The degree of determination $\left(\mathrm{R}^{2}\right)=0.289$, meaning that only $28.9 \%$ of the nodule weight variability can be explained by the $\mathrm{Y}\left(\mathrm{M}_{2}\right)$ equation. The weight of nodules when given humic acid at an AMF dose of $2.5 \mathrm{~g} \mathrm{plant}^{-1}\left(\mathrm{M}_{1}\right)$ forms the equation $\mathrm{Y}\left(\mathrm{M}_{1}\right)=0.0086 \mathrm{x}+0.1283$, meaning that any increase in the concentration of humic acid at an AMF dose of 2.5 g plant $^{-1}$ will be accompanied by an increase in root nodules weight of $0.0086 \mathrm{~g}$. The maximum nodule weight achieved from $45 \mathrm{~mL} \mathrm{~L}^{-1}$ of humic acid with $2.5 \mathrm{~g} \mathrm{plant}^{-1}$ AMF is $0.51 \mathrm{~g}$. The value of determination, $\mathrm{R}^{2}$, is 0.2959 , indicating that the $\mathrm{Y}\left(\mathrm{M}_{1}\right)$ equation can only explain $29.59 \%$ of the variability of nodule weight (Figure 2).

On the other hand, giving humic acid without AMF inoculation formed a quadratic pattern of nodule weight, with the equation $\mathrm{Y}\left(\mathrm{M}_{0}\right)=0.0001 \mathrm{x}^{2}+0.005 \mathrm{x}+$ 0.0577 and $\mathrm{R}^{2}=0.9547$. Given the optimum concentration of humic acid, $25 \mathrm{~mL} \mathrm{~L}^{-1}$, the maximum nodule weight will be $0.12 \mathrm{~g}$. However, giving humic acid above the optimum concentration will reduce nodules' weight (Figure 2). That because humic acid can inhibit urease activity (protein in bacteria) that can reduce nitrogen released through evaporation so that nitrogen availability in the soil increases.

The interaction of humic acid and AMF, apart from being significantly different in soil $\mathrm{pH}$ and nodule weight, also significantly different at plant height. Further tests on plant height are presented in Figure 3. The relationship between humic acid concentration and plant height, when inoculated with AMF $2.5 \mathrm{~g}$ plant $^{-1}\left(\mathrm{M}_{1}\right)$, formed a positive linear pattern, $\mathrm{Y}\left(\mathrm{M}_{1}\right)=0.1212 \mathrm{x}+39.129$ with the degree of determination of $\left(\mathrm{R}^{2}\right)=0.4802$. That indicates that each addition of humic acid concentration at the AMF dose of $2.5 \mathrm{~g} \mathrm{plant}^{-1}$ will increase the plant height by $0.1212 \mathrm{~cm}$. On the other hand, the relationship between plant height and humic acid concentration when inoculated with AMF $5 \mathrm{~g}_{\text {plant }}{ }^{-1}$ formed a negative linear pattern, with the equation $\mathrm{Y}\left(\mathrm{M}_{2}\right)=-0.1676 \mathrm{x}+39.783$ and $\mathrm{R}^{2}=0.7102$. Each addition of humic acid concentration at the AMF dose of 5 g plant $^{-1}$ will inhibit plant height growth by $0.1676 \mathrm{~cm}$. Different things were obtained when given humic acid without inoculating $\operatorname{AMF}\left(\mathrm{M}_{0}\right)$, forming a quadratic relationship pattern with equation $\mathrm{Y}\left(\mathrm{M}_{0}\right)=$ $-0.0418 x^{2}+1.7636 x+35.091$. Giving humic acid independently at an optimal concentration of 21.09 $\mathrm{mL} \mathrm{L}^{-1}$ will get a maximum plant height of $53.69 \mathrm{~cm}$. However, offering humic acid above the optimal concentration will inhibit plant height growth by $0.0418 \mathrm{~cm}$. The value of $\mathrm{R}^{2}=0.8738$, meaning that $87.38 \%$ of plant height variability can be represented by the $\mathrm{Y}\left(\mathrm{M}_{0}\right)$ equation (Figure 3 ). 
Soybean growth is influenced by variety, environment, and nutrient population. Based on the variety's description, the actual plant height can reach 64-68 $\mathrm{cm}$, with a definite type of growth. The research results from presenting humic acid and AMF inoculation at various levels tended to form low-growing plants from the actual plant posture. This is thought to be due to a lack of nutrient intake during the plant's vegetative phase. Soybean plants absorb significant amounts of $\mathrm{N}, \mathrm{P}, \mathrm{K}, \mathrm{Ca}, \mathrm{Mg}, \mathrm{S}$, and $\mathrm{Cl}$ from the soil, but soybeans are generally less responsive to direct fertilization (Sumarmono \& Manshuri, 2013).

Growth indicators other than plant height can also be seen in the number of leaves - the relationship between the number of leaves and humic acid concentration at several AMF doses presented in Figure 4. Leaves are an important indicator of early soybean plant growth. Leaves as a place for photosynthesis to occur; in other words, the more leaves, the more energy can be produced. The number of leaves is influenced by the variety and environment as well as the availability of nutrients. The highest number of leaves from this study was obtained from the optimum concentration of humic acid at $21.09 \mathrm{~mL} \mathrm{~L}^{-1}$ independently, which was 13.43 leaves (Figure 4). Compared with Sumarmi \& Tryono's research (Sumarmi \& Triyono, 2018) stated in the same variety as this study, when normal conditions can produce 17 leaves. That indicates that neither humic acid nor AMF has provided an optimal response to the number of leaves (Figure 3).

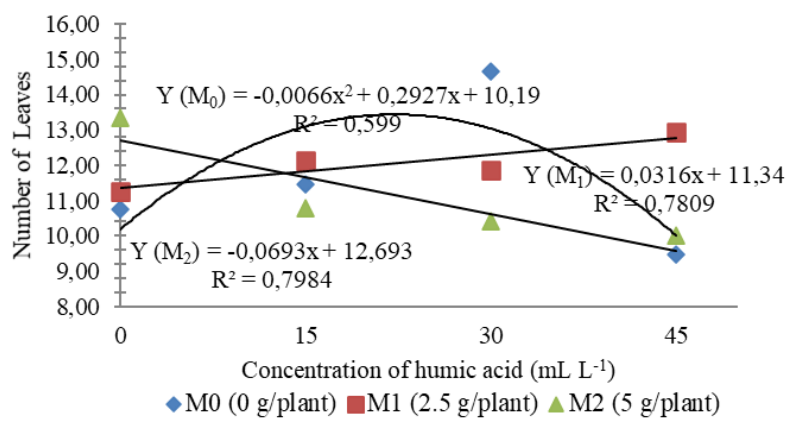

Figure 4. Relationship of humic acid concentration and number of leaves at several AMF doses

The interaction of humic acid and AMF inoculation also significantly affected the P-tissue content. The relationship between P-tissues content and humic acid concentration at several AMF doses presented in Figure 5. Giving humic acid with a concentration of $45 \mathrm{~mL} \mathrm{~L}^{-1}$ at an AMF dose of $5 \mathrm{~g} \mathrm{plant}^{-1}$ was able to provide a maximum P-tissue content of $1.89 \%$ (Figure 5). That is presumably because the addition of humic acid can release the $\mathrm{P}$ bonds bound to the Ultisols soil into cations that can be absorbed by plant roots characterized by soil $\mathrm{pH}$ that is close to normal 6.07
(Figure 1). In line with Bertham's research (Bertham, 2002), increasing the $\mathrm{pH}$ of acidic soil will cause a decrease in the solubility of $\mathrm{Al}$ ions so that they can be exchanged because organic acid scan classify metal ions. Consequently, inorganic phosphorus ions will be released into the soil, which will then be absorbed by plants. This is also confirmed by Nurhayati (Nurhayati, 2012), which states that the main function of hyphae in AMF is to absorb water from the soil, $\mathrm{P}$ that accumulates in external hyphae will immediately be converted into polyphosphate compounds in the presence of the enzyme phosphatase. Thus, the interaction of $45 \mathrm{~mL} \mathrm{~L}^{-1}$ humic acid concentration at an AMF dose of $5 \mathrm{~g}$ plant $^{-1}$ positively affected the P levels of plant tissue.

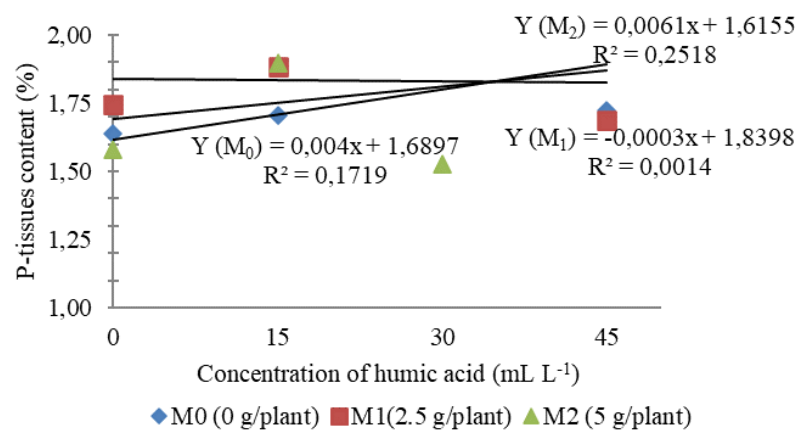

Figure 5. Relationship of humic acid concentr tion and P-tissues content at several AMF doses

Further tests of seed weight per plant from humic acid concentration at several AMF doses are presented in Figure 6. The maximum potential seed weight per plant from the application of humic acid $45 \mathrm{~mL} \mathrm{~L}^{-1}$ to the AMF 2.5 g plant $^{-1}$ inoculation was 13.31 g plant $^{-1}$ or equivalent to 1.99 tons ha $^{-1}$ (Figure 6). Compared with the soybean varieties used, it has a yield potential of 2.03-2.25 tons ha ${ }^{-1}$. The interaction between humic acid and AMF is still $1.97 \%$ less to achieve the real yield potential. The weight of seeds by the interaction between the humic acid concentration of $45 \mathrm{~mL} \mathrm{~L}^{-1}$ with an AMF dose of $2.5 \mathrm{~g}$ plant $^{-1}$ has a positive linear relationship (Figure 6). it means that the seed weight per plant has the potential to increase if the humic acid concentration increases at an AMF inoculation of $2.5 \mathrm{~g} \mathrm{plant}^{-1}$ on Ultisol soil.

Seed weight is closely related to the seed filling process that starts in the R5 phase. Based on the varieties used, this phase occurs after 40 days after planting. The seeds' size in the pods until $3 \mathrm{~mm}$ in one of the stem nodes (Adie \& Krisnawati, 2013). Judging from the optimal work of humic acid on improving soil properties, on the first 45 days, the second 45 days performance of humic acid tends to decline (Wahyudi, 2007). On the other hand, during that time, the FMA inoculant will work optimally to absorb nutrients, 
especially $\mathrm{P}$. This statement supposed by Malik et al. (2017) stated that ripening fruit/grain and increasing grain production is highly dependent on the nutrient P. This indirectly emphasizes that the interaction between humic acid and AMF synergizes in increasing soybean production in Ultisols.

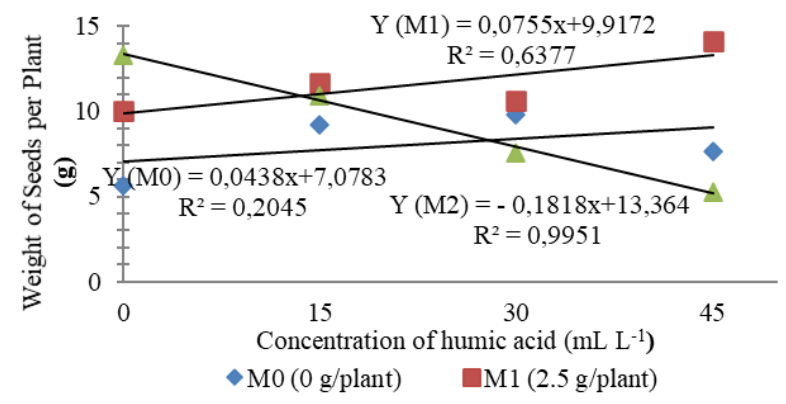

Figure 6. Relationship of humic acid concentration and weight of seeds per plant at several AMF doses

Further tests for the number of root nodules and the weight of dray stover from the humic acid concentration are presented in Figures 7 and 8.

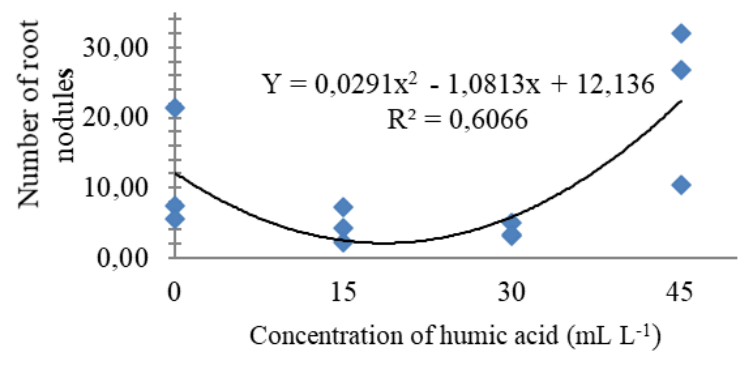

Figure 7. Relation of humic acid concentration and number of root nodules

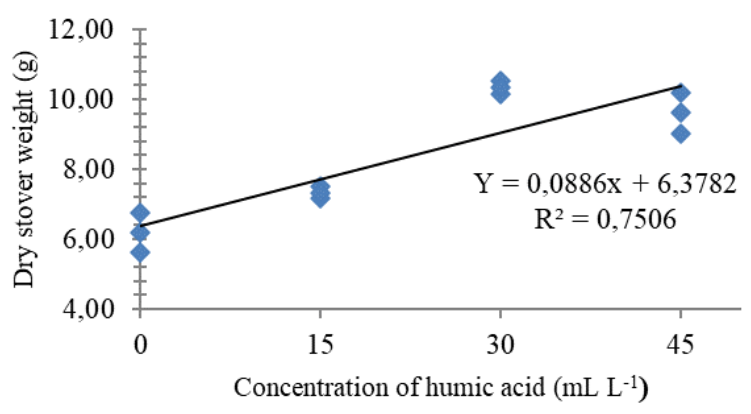

Figure 8. Relationship of humic acid concentration and dry stover weight

The relationship between the number of nodules and the humic acid concentration of $0-45 \mathrm{~mL}$ $\mathrm{L}^{-1}$ formed a parabolic quadratic pattern with the equation $\mathrm{Y}=0.0291 \mathrm{x}^{2}-1.0813 \mathrm{x}+12.136$. Giving the optimum concentration of humic acid, namely 18.57 $\mathrm{mL} \mathrm{L}^{-1}$, will provide a minimum value for the number of nodules. The degree of determination of this equation is $\mathrm{R}^{2}=0.6066$. It means that the equation can explain $60.6 \%$ of the number of nodules' variability from the concentration of humic acid for the number of nodules (Figure 7).

A large number of nodules do not necessarily indicate good results for the plant. Root nodules will have a positive value if the root nodules are healthy or effective at tethering N. Conversely, a large number of root nodules that are not effective at fixing $\mathrm{N}$ will inhibit the growth and yield of soybean plants. The infectivity and effectiveness of natural Rizhobium in soybean plants. However, infection of all Rizhobium strains in acidic soils very slow, especially at $\mathrm{pH} 4.5$ or lower (Taufik \& Sundari, 2003). Although the humic acid application has shown an increase in soil $\mathrm{pH}$, namely 6.07 (Figure 1), it has not positively affected Rizhobium on soybean roots, presumably because the soil conditions have never been planted with legume plants before. Apart from root nodules, humic acid also significantly affected the dry stover weight - further tests on dry stover weight presented in Figure 8.

The humic acid concentration of $45 \mathrm{~mL} \mathrm{~L}^{-1}$ resulted in a maximum dry stover weight of $10.36 \mathrm{~g}$ (Figure 8). This result corroborated by Wahyuningsih et al. (2016) stated that giving humic acid could increase the dry stover weight of soybean plants. Increased dry stover weight reflects the number of nutrients absorbed by plants. Stevenson (1994) explained in Hermanto et al. (2013) explains that one of the importance of humic is the humic fraction can provide nutrients such as $\mathrm{N}, \mathrm{P}, \mathrm{K}$, and $\mathrm{S}$ into the soil and $\mathrm{C}$ as a source of energy for soil microbes. The results of this study suggest that the dry stover weight consists of various nutrients that have been provided by humic acid to plants.

In general, humic acid independently has no significant effect on yield variables commonly. Meanwhile, in terms of seed weight per plant, the highest yield was obtained from the humic acid concentration of $15 \mathrm{~mL} \mathrm{~L}^{-1}$, amounting to $10.6 \mathrm{~g} \mathrm{plant}^{-1}$ or equivalent to a 1.59 tons $\mathrm{ha}^{-1}$ production. If compared with the variety description, this result is $21.67 \%$ lower than the real potential that is between 2.03-2.25 tons ha ${ }^{-1}$. However, giving humic acid to Ultisol increased the yield $9.95 \%$ higher than without humic acid administration.

The relation between AMF and root colonization, number of seeds per plant, and dry stover weight presented in Figures 9, 10, and 11.

Inoculation of AMF 0-5 $\mathrm{g} \mathrm{plant}^{-1}$ to the percentage of root colonization forms a quadratic pattern relationship, with the equation $Y=-2,8 x^{2}+22 x+$ 21,25 . The percentage of root colonization increased 
as the AMF dose was increased to the optimum dose, at $3.92 \mathrm{~g} \mathrm{plant}^{-1}$. The optimum dose has the potential to produce a percentage of root colonization of $64.46 \%$. Inoculation of AMF above the optimum dose will decrease the percentage of colonization by $2.8 \%$. The coefficient of determination $\left(\mathrm{R}^{2}\right)$ of 0.9728 indicates that the AMF quadratic function can determine $97.28 \%$ of the variability in the percentage of root colonization. In other words, $2.72 \%$ of colonization was caused by influences outside the treatment factors (Figure 9).

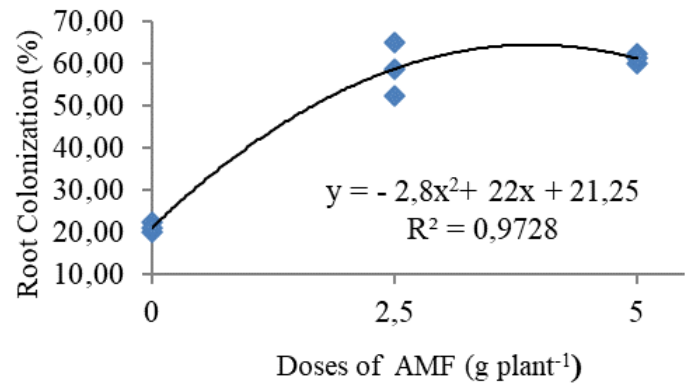

Figure 9. Relationship of AMF and root colonization

Root colonization is a form of the symbiotic process between the host plant roots and AMF (Muryati et al., 2016). Root colonization as an important role in the performance of the roots in absorbing nutrients. Besides affecting root colonization, AMF inoculation also significantly affected the number of seeds per plant and dry stover weight. The relationship of AMF inoculation to the number of seeds per plant is presented in Figure 10.

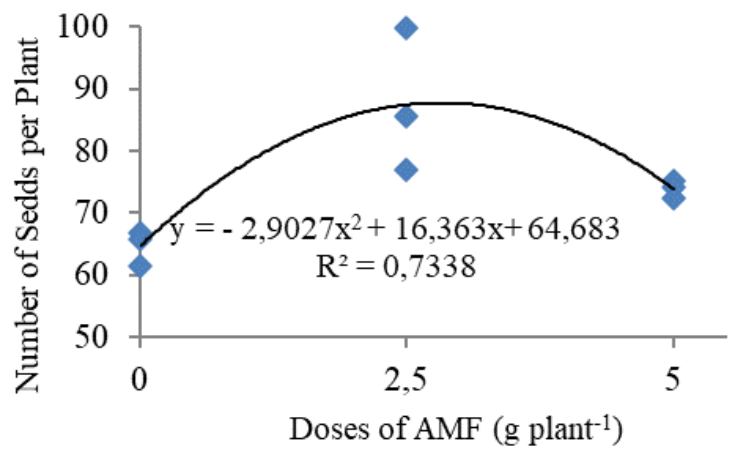

Figure 10. Relationship of AMF and number of the seeds

Inoculation of AMF 0-5 g plant ${ }^{-1}$ to the number of seeds per plant formed a quadratic pattern following the equation $Y=-2,9027 x^{2}+16,363 x+$ 64,683 . Indicated that the number of seeds per plant could increase to the optimum point of AMF at a dose of $2.81 \mathrm{~g} \mathrm{plant}^{-1}$, potentially producing a total number of seeds per plant as much as 87.74 seeds.
Inoculation of AMF above the optimum dose will reduce the number of seeds by 2.9 seeds. The value of the degree of determination $\mathrm{R}^{2}$ is 0.7338 indicates that $73.38 \%$ of the variability of the number of seeds per plant can be determined by the AMF dose equation (Figure 10). This result is indirectly in line with the research of Sabilu et al. (2015) stated that the number of seeds per soybean plant with the same variety on Ultisols soil with the provision of $30 \mathrm{~g}$ mycorrhizae, namely 83 seeds. However, from an economic point of view, the AMF inoculation of 2.81 g plant $^{-1}$ was effective enough to obtain the maximum number of seeds in Ultisols soil.

Apart from the number of seeds planted, AMF also significantly affected the dry stover weight, presented in Figure 11. The orthogonal polynomial test on dry stover weight from AMF doses at 0-5 g plant $^{-1}$ formed a positive linear response pattern. The equation is $\mathrm{Y}=0.5459 \mathrm{x}+7.0062$, meaning that the dry stover weight will increase by $0.5642 \mathrm{~g}$ as the AMF dose increased also. The coefficient of determination $\mathrm{R}^{2}=0.5617$, meaning that $56.17 \%$ of the variability of dry stover weight can be determined from the AMF equation (Figure 11). Plant dry weight from AMF inoculation will continue to increase with increasing AMF dose, meaning that AMF positively affects plant dry weight. That is presumably due to infection by AMF, a significant of AMF inoculation on the percentage of root colonization (Figure 9). AMF helped absorb immobile nutrients such as $\mathrm{P}$ to use as a plant metabolic process in Ultisol (Malik, 2017).

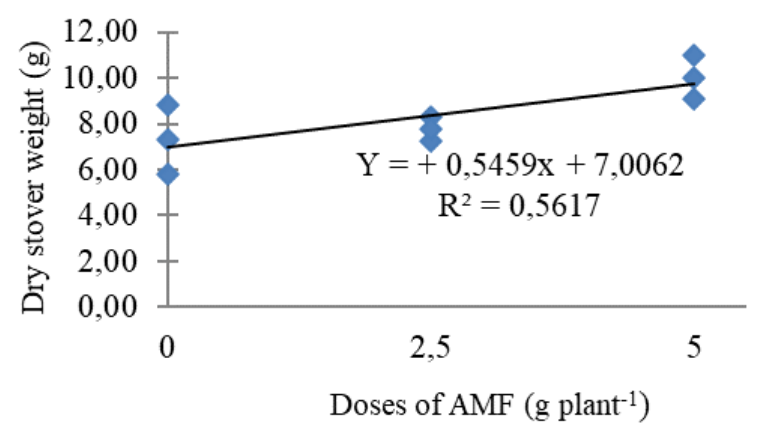

Figure 11. Relationship of AMF and dry stover weight

In general, the yield of soybean from AMF inoculation tends to be high at a dose of $2.5 \mathrm{~g} \mathrm{plant}^{-1}$. The highest seed weight per plant was $2.5 \mathrm{~g} \mathrm{plant}^{-1}$, amounting to $11.62 \mathrm{~g}$ or equivalent to 1.74 tons $\mathrm{ha}^{-1}$ '. When compared with the yield potential in the variety description, between $2.03-2.25$ tons $\mathrm{ha}^{-1}$, the yield from this research is still $14.28 \%$ less towards the actual yield potential of soybeans. However, inoculation AMF 2.5 g plant $^{-1}$ in Ultisol obtained $44.16 \%$ higher results than without AMF inoculation.

Inoculation of AMF independently in this study did not run optimally on the growth and yield of 
soybeans. It means that to be due to the less than optimal AMF performance, but there is a possibility that the nutrient is indeed in small amounts in Ultisol soil. In terms of the results obtained, AMF inoculation when compared to humic acid administration. AMF inoculation tended to give superior results than the administration of humic acid independently. The status of AMF as a microorganism can produce nutrients that are useful for plants. The AMF gets its energy from the application of organic fertilizers, with cow manure applied before planting. In another case, the humic acid is not a kind of fertilizer. Still, as a chemical element, it just interacts intensively with soil chemical properties and carries little nutrients to plants. The amount of nutrients humic acid can extract depends on the matter of humic acid was made and the total nutrient content stored in the soil. In other words, the independent application of humic acid must be accompanied by an adequate intake of additional nutrients in less fertile soils.

\section{CONCLUSION}

The interaction of $45 \mathrm{~mL} \mathrm{~L}^{-1}$ humic acids at AMF $2.5 \mathrm{~g}$ plant $^{-1}$ inoculation was the optimum concentration for growth and yield of soybean in Ultisols. The yield potential obtained is equivalent to 1.99 tons $\mathrm{ha}^{-1}$. The interaction is still $1.97 \%$ less than the potential production of soybean in Ultisols. The administration of humic acid or AMF independently at this research stage had not yet given a maximum response to the growth and yield of soybean in Ultisol.

\section{References}

Adie, M., \& Krisnawati, A. (2013). Biologi Tanaman. In Sumarmono, Suyanto, A. Widjono, Hermanto, K.H. Kedelai (Teknik Produksi dan Pengembangan) (pp. 45-73). Balai Penelitian Tanaman Kacang-kacangan dan Umbi-umbian , Malang.

Al Ghifari, M., Tyasmoro, S. \& Soelistyo, R. (2014). Pengaruh kombinasi kompos kotoran sapi dan paitan (Tithonia diversifolia L.) terhadap produksi tanaman cabai keriting (Capsicum annum L.). Jurnal Produksi Tanaman, 31-40.

Badan Pusat Statistik. (2016). Retrieved April 18, 2019, from https://www.bps.go.id.

Badan Pusat Statistik. (2019). Retrieved June 10, 2020, from https://www.bps.go.id/statictable/ 2019/02/14/2015/impor-kedelai-menurutnegara-asal-utama-2010-2019.html.

Balai Penelitian Tanah. (2009). Petunjuk Teknis Edisi 2: Analisis Kimia Tanah, Tanaman, Air, dan Pupuk. Balai Penelitian Tanah, Bogor.

Barchia, M. (2008). Agroekosistem Tanah Mineral Masam. Gadjah Mada University Press., Yogyakarta.
Bertham, Y. (2002). Potensi pupuk hayati dalam peningkatan produktivitas kacang tanah dan kedelai pada tanah Seri Kandang Limun Bengkulu. Jurnal Ilmu-ilmu Pertanian Indonesia, 18-26.

Gomez, K. \& Gomez, A. (1983). Statistical Procedures for Agricultural Research (Second edition). Wiley and Sons., New York.

Hakim, D. (2019). Ensiklopedia Jenis Tanah di Dunia. Uwais Inspirasi Indonesia, Ponorogo.

Handayanto, E., Muddarisna, N. \& Fiqri, A. (2017). Pengelolaan Kesuburan Tanah. University Brawijaya, Malang.

Hermanto, D., Dharmayani, N., Kurnianingsih, R. \& Karnali, S. (2013). Pengaruh asam humat sebagai pelengkap terhadap ketersediaan dan pengambilan nutrien pada tanaman jagung di lahan kering Kec. Bayan-NTB. Jurnal Ilmu Pertanian, 28-41.

Khairuna, Syafarudidin \& Marlina. (2015). Pengaruh mikoriza arbuskular dan kompos pada tanaman kedelai terhadap sifat kimia tanah. Jurnal Floratek, 1-9.

Malik, M., Hidayat, K., Yusnaini, S. \& Rini, M. (2017). Pengaruh aplikasi fungi mikoriza Arbuskula dan pupuk kandang dengan berbagai dosis terhadap pertumbuhan dan produksi kedelai (Glycine max (L.) Merrill) pada Ultisol. Jurnal Agrotek Tropika , 63-67.

Muryati, S., Mansur, I., \& Budi, S. (2016). Keanekaragaman fungi mikoriza arbuskula (FMA) pada rhizosfer Desmodium spp. asal PT. Cibaliung Sumberdaya, Banten. Jurnal Silvikultur Tropika, 188-197.

Nurhayati, N. (2012). Pengaruh berbagai jenis tanaman inang dan beberapa jenis sumber inokulum terhadap infektivitas dan efektivitas mikoriza. Jurnal Agrista, 80-86.

Pertanian, K. (2018). Rencana Strategis-Penelitian dan Pengembangan Sumberdaya Lahan Pertanian. Balai Besar Penelitian dan Pengembangan Lahan Pertanian, Bogor.

Purwati, B., Budi, S. \& Waris, B. (2019). Status fungi mikoriza arbuskular (FMA) pada rizosfer Jernang (Daemonorops draco Blume) di Jambi. Jurnal Media Konversi, 261-268.

Ruhaimah, Asmar \& Harianti, M. (2009). Efek Sisa asam humat dari kompos jerami padi dan pengelolaan air dalam mengurangi keracunan besi $(\mathrm{Fe})$ tanah sawah bukaan baru terhadap produksi padi. Jurnal Solum, 1-13.

Sabilu, Y., Damhuri \& Imran. (2015). Kadar N, P dan K kedelai (Glycine max (L) Merrill) yang diaplikasi Azotobacter sp., mikoriza dan pupuk organik. Jurnal Penelitian Biologi, 153-161.

Satosa, S. (2014). Dekontaminasi Ion Logam dengan Biosorben Berbasis Asam Humat, Kitin dan 
Kitosan. Gadjah Mada University Press., Yogyakarta.

Statistik, B. P. (2019). Retrieved from https:// www.bps.go.id/statictable/2019/02/14/2015/ impor-kedelai-menurut-negara-asal-utama2010-2019. html.

Stevenson. (1994). Humus Chemistry-Genesis, Composition, Reaction, second edition. University of Illinois, Canada.

Sumarmi, \& Triyono, K. (2018). Pertumbuhan dan hasil penanaman kedelai (Glycine max L. Merrill) varietas Grobokan dan Anjasmoro akibat kekeringan di Sidoharjo, Kabupaten Wonogiri. Jurnal Inovasi Pertanian, 1-12.

Sumarmono \& Manshuri, A. (2013). Persyaratan Tumbuh dan Wilayah Produksi Kedelai di Indonesia. In Sumarmono, Suyanto, A. Widjono, Hermanto, \& H. Kasim, Kedelai (Teknik Produksi dan Pengembangan) (pp. 74-103). Pusat Penelitian dan Pengembangan Tanaman Pangan, Malang.

Taufik, A. \& Sundari, T. (2003). Respon tanaman kedelai terhadap lingkungan tumbuh. Buletin Palawija, pp. 13-26.
Utama, M., \& Yahya, S. (2003). Peranan mikoriza VA, rhizobium dan asam humat pada pertumbuhan dan kadar hara beberapa spesies legum penutup tanah. Buletin Agron, 94-99.

Wahyudi, I. (2007). Peran asam humat dan fulvat dari kompos dalam deteksifiksasi aluminium pada tanah masam. Jurnal Buana Sains, 123130.

Wahyuningisih, Proklamasiningsih, E. \& Dwita, M. (2016). Serapan fosfor pada kedelai (Glychie max) di tanah Ultisol dengan pemberian asam humat. Jurnal Biosfera, 66-70.

Wardhani, Y., Yuliana, A., \& Munir, M. (2019). Potensi mikoriza indigenous terhadap serapan unsur P (fosfor) di tanah Ultisol pada tanaman kedelai (Glycine max. L. Merrill) varietas Anjasmoro. Jurnal Exact Papers in Compilation, 83-86.

Winarsi, H. (2010). Protein Kedelai dan Kecambah Manfaatnya Bagi Kesehatan. Kanisus, Yogyakarta. 